\title{
Season production of 11 Panicum maximun cultivars harvested at a 45-day interval'
}

\author{
Rafael Ramos-Santana and José E. Rodriguez-Arroyo ${ }^{g}$
}

\begin{abstract}
The productive potential of 11 guinea grass forage genotypes was evaluated at harvest intervals of $\mathbf{4 5}$ days during the short and long day seasons. Guinea grass genotypes PRPI 3637 and 3622 produced the highest dry matter yields. P. maximun PRPI 12917 (cultivar Makueny) was not different from 3637 or 3622 during short days; however, during long days it differed from cultivar 3637. In vitro true digestibility (IVTD) estimated by the predicting equation of Arroyo-Aguilú and Coward-Lord was similar for most cultivars under evaluation. Cultivar Guadalupe produced the highest IVTD values during both seasons. Among all genotypes, P. maximun 3637 and 3634 consistently had the highest average regrowth percenfages and the best capacity to recover.
\end{abstract}

\section{RESUMEN}

Producción estacional de 11 genotipos de yerba guinea cosechados cada 45 días

Se evaluó el potencial de producción de 11 genotipos de $P$. maximun cortados cada 45 días. En las épocas de días largos y cortos y durante el año entero la selección PRPI 3637 y 3622 fueron las de mayor producción de materia seca. PRPI 12917 (cultivar Makueny) no tuvo diferencias significativas en producción de materia seca sobre PRPI 3637 ni PRPI 3622 en los días cortos, pero durante los días largos solo fue significativamente inferior que PRPI 3637. Los estimados de digestibilidad verdadera in vitro con la ecuación sumativa de Arroyo-Aguilú y Coward-Lord fueron similares para la mayor parte de los genotipos evaluados. Los genotipos PRPI 3637 y 3734 mostraron consistentemente los más altos promedios de porcentajes de rebrote y mostraron mejor capacidad para recabrar que los demás genotipos evaluados.

\section{INTRODUCTION}

Guinea grass (Panicum maximun; Jacq) is one of the best adapted tropical forages. It produces yields in a variety of soil and climatic conditions and adapts well to different animal feeding systems such as grazing, soilage, hay and silage $(6,7)$. Although guinea grass is an excellent forage crop, the low seed germination percentages of some genotypes limit its use (3).

'Manuscript submitted to Editorial Board 24 May 1990.

${ }^{2}$ Research Assistant, Department of Agronomy.

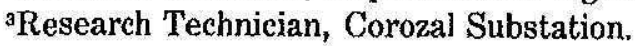


Various studies have been conducted in different ecological areas of Puerto Rico to evaluate the dry matter yield potential of different guinea grass accessions $(4,7,8,9,10,11)$. At the Gurabo Substation SotomayorRíos et al. (7), using harvest intervals of 60 days, found that $P$. maximun cultivar PRPI 3622 produced $53,476 \mathrm{~kg} / \mathrm{ha} /$ year of dry forage. At the Lajas Substation with harvest intervals of 42 days and irrigation, $P$. maximun cultivars PRPI 13093, 13092, and 12917 had dry forage yields of $45,574,40,267$ and $44,811 \mathrm{~kg} / \mathrm{ha}$, respectively, in a 378-day period. Genotype Makueny (PRPI 12917) produced significantly higher yields between October and March, when shorter day lengths and cooler temperatures prevail (9).

The objectives of our study were 1) to compare the forage yield and adaptation of 11 guinea grass accessions at harvest intervals of 45 days, and 2) to continue another year of evaluation with cattle grazing on the same plots as recommended by Mott (5).

\section{MATERIALS AND METHODS}

Eleven guinea grass accessions were evaluated in a balanced incomplete block design with four replications from 22 September 1987 to 19 September 1988. The experiment was conducted at the Corozal Agricultural Experiment Station on a Corozal clay soil (Aquic Tropudults). Soil $\mathrm{pH}$ was raised to 5.5 by applying limestone before planting. Total annual precipitation was $2121 \mathrm{~mm}$ and the mean daily temperature was $25.10^{\circ}$ $\mathrm{C}$ during the experimental period.

For propagation, 28 grown clusters of guinea grass accessions were planted in four rows on each $12.5 \mathrm{~m}^{2}$ plot. During the establishment period all plots received $336 \mathrm{~kg} / \mathrm{ha}$ of a commercial 15-5-10 fertilizer. During the year after this establishment, each plot was fertilized at a rate of $3,366 \mathrm{~kg} / \mathrm{ha}$ of the same fertilizer divided into eight applications done shortly after harvest. The plots were cut $15 \mathrm{~cm}$ from the ground every 45 days for determining dry matter yield during both the short and long dry seasons.

Plant height $(\mathrm{PH})$ was obtained by measuring from the ground to the top leaves of three plants randomly selected from every plot. Measurements were made on regrowth 15,30 and 45 days after one harvest during the short day season, and one harvest during the long day season. Average regrowth percentage (APR) was calculated by the following formula:

$$
\mathrm{APR}=\frac{\mathrm{PH} \text { at } 30 \text { days }-\mathrm{PH} \text { at } 15 \text { days }}{\mathrm{PH} \text { at } 15 \text { days }}+\frac{\mathrm{PH} \text { at } 45 \text { days }-\mathrm{PH} \text { at } 30 \text { days }}{\mathrm{PH} \text { at } 30 \text { days }} \div 2 \times 100
$$

The method of Goering and Van Soest (2) and the additive equation of Arroyo-Aguilú and Coward-Lord (1) were used to estimate the per- 
centage of in vitro true digestible dry matter (IVTD) from a composite forage sample of four plots from harvests during the middle of the long and short day seasons. The equation used for IVTD was as follows:

$$
\begin{gathered}
\text { IVTD }=96.86+.62(\% \mathrm{CP})-.51(\% \mathrm{C})-2.59(\% \mathrm{~L})-2.34(\mathrm{Si}) \text {, where } \% \\
\mathrm{CP}=\text { percent crude protein, } \% \mathrm{C}=\text { percent cellulose, } \% \mathrm{~L}=\text { percent } \\
\text { lignin and } \% \mathrm{Si}=\text { percent silica. }
\end{gathered}
$$

Analysis of variance and Duncan's multiple range $(P=0.05)$ were used to compare the performance of the forage accessions.

\section{RESULTS AND DISCUSSION}

In comparison with the other genotypes in the trial, $P$. maximun genotypes PRPI 3637 and 3622 produced significantly more dry matter yields when harvested at 45-days intervals during the 1987-88 growing season (table 1). The results are in contrast with those of Sotomayor et al. (7), in which P. maximun PRPl 3622 had significantly higher yields than the other $15 P$. maximun genotypes harvested at an interval of 60 days. It should be noted, however, that cultivar Makueny PRPI 12917 did not differ significantly in dry matter yield from the above mentioned genotypes during the short-day season. This finding agrees with the results of Vélez-Santiago et al. (9) at Lajas during the short-day season, in which cultivar Makueny was one of the highest yielding cultivars. During the long-day season, cultivars $P$. maximun PRPI 3634, 12917 and common guinea grass had dry matter yields similar to that of $P$.

TABLE 1.-Mean dry matter yield of eleven Panicum maximun genotypes evaluated using harvest intervals of 45 days during the 1987-88 growing season

\begin{tabular}{cccc}
\hline $\begin{array}{c}\text { Identification } \\
\begin{array}{c}\text { P.R.P.I. or } \\
\text { common name }\end{array}\end{array}$ & $\begin{array}{c}\text { Dry matter yield } \\
\mathrm{kg} / \mathrm{ha}\end{array}$ & $\begin{array}{c}\text { Dry matter yield } \\
\mathrm{kg} / \mathrm{ha}\end{array}$ & $\begin{array}{c}\text { Dry matter yield } \\
\mathrm{kg} / \mathrm{ha}\end{array}$ \\
\hline & September to Febmuary & March to August & Yearly tolal \\
& & & \\
3637 & $18,918 \mathrm{ab}^{1}$ & $23,140 \mathrm{a}$ & $42,061 \mathrm{a}$ \\
3622 & $18,739 \mathrm{ab}$ & $21,039 \mathrm{ab}$ & $39,777 \mathrm{a}$ \\
3634 & $15,820 \mathrm{~cd}$ & $19,651 \mathrm{bcd}$ & $35,470 \mathrm{bc}$ \\
12917 & $16,893 \mathrm{bc}$ & $18,223 \mathrm{bcde}$ & $35,117 \mathrm{c}$ \\
13093 & $14,172 \mathrm{~d}$ & $20,629 \mathrm{abc}$ & $34,804 \mathrm{c}$ \\
Common & $14,485 \mathrm{~cd}$ & $18,721 \mathrm{bede}$ & $33,614 \mathrm{~cd}$ \\
Sp. & $14,485 \mathrm{~cd}$ & $17,891 \mathrm{cdef}$ & $32,371 \mathrm{cde}$ \\
Guadalupe & $11,670 \mathrm{e}$ & $17,396 \mathrm{defg}$ & $29,065 \mathrm{efg}$ \\
13605 & $14,229 \mathrm{~d}$ & $14,642 \mathrm{~g}$ & $28,869 \mathrm{efg}$ \\
13606 & $11,705 \mathrm{e}$ & $15,078 \mathrm{~g}$ & $26,781 \mathrm{fg}$ \\
1987 & $10,253 \mathrm{e}$ & $15,418 \mathrm{fg}$ & $25,656 \mathrm{~g}$ \\
Mean & 14,707 & 18,348 & 33,053 \\
\hline
\end{tabular}

'Means followed by the same letter or letters do not differ at the 0.05 probability level 
TABLE 2.-In vitro true digestibility (IVTD) of all cultivars according to the predicting equation of Arroyo-Aguilu and Coward-Lord (1) during short and long day season

\begin{tabular}{cccc}
\hline $\begin{array}{c}\text { Identification } \\
\text { P.R.P.I. or } \\
\text { common name }\end{array}$ & $\begin{array}{c}\text { IVTD } \\
\text { December }\end{array}$ & $\begin{array}{c}\text { IVTD } \\
\text { June }\end{array}$ & $\begin{array}{c}\text { Average } \\
\text { IVTD }\end{array}$ \\
\hline & $\%$ & $\%$ & \\
13605 & 54.34 & 59.87 & 56.60 \\
Guadalupe & 52.35 & 59.15 & 55.75 \\
Sp. & 53.22 & 54.36 & 54.79 \\
1987 & 51.01 & 57.93 & 54.47 \\
12917 & 52.82 & 55.68 & 54.25 \\
13093 & 51.76 & 55.73 & 53.74 \\
3637 & 48.48 & 59.13 & 53.80 \\
Common & 45.64 & 60.92 & 53.28 \\
3634 & 53.01 & 51.87 & 52.44 \\
3622 & 48.87 & 53.84 & 51.35 \\
13606 & 45.46 & 57.11 & 51.28 \\
Mean & 50.52 & 56.87 & 53.79 \\
\hline
\end{tabular}

maximun 3622. However, the yields of PRPI 13093, 3637 and 3622 were all excellent during the long dry season. When both seasons were combined cultivars 3637 and 3622 significantly outyielded the other cultivars.

Table 2 presents the predicted IVTD of the 11 cultivars under evaluation according to the equation of Arroyo-Aguilu and Coward-Lord (1).

TABLE 3.-Average plant height $(\mathrm{cm})$ and average regrowth percentages (APR\%) at 15 , 80 and 45 days intervals during long days season (July to August, 1988)

\begin{tabular}{|c|c|c|c|c|}
\hline \multicolumn{5}{|c|}{ Days of regrowth } \\
\hline $\begin{array}{l}\text { Identification } \\
\text { P.R.P.I. or } \\
\text { common name }\end{array}$ & 15 days & 30 days & 45 days & ARP \\
\hline & & $m-\cdots$ & -....-.- & $\%$ \\
\hline 3637 & 21 & 81 & $142 \mathrm{a}^{\mathrm{b}}$ & 180 \\
\hline 3634 & 27 & 80 & $127 \mathrm{~b}$ & 127 \\
\hline 3622 & 26 & 64 & $107 \mathrm{c}$ & 106 \\
\hline 13093 & 25 & 59 & $106 \mathrm{c}$ & 108 \\
\hline Sp. & 22 & 57 & $100 \mathrm{~cd}$ & 117 \\
\hline Common & 24 & 60 & $100 \mathrm{~cd}$ & 108 \\
\hline 12917 & 29 & 61 & 85 ef & 74 \\
\hline 13605 & 17 & 44 & $78 \mathrm{fg}$ & 118 \\
\hline 13606 & 21 & 51 & $72 \mathrm{gh}$ & 92 \\
\hline 1987 & 15 & 35 & $67 \mathrm{gh}$ & 112 \\
\hline Guadalupe & 15 & 34 & $64 \mathrm{~h}$ & 107 \\
\hline Mean & 22 & 57 & 95 & 113 \\
\hline
\end{tabular}

'Means followed by the same letter or letters do not differ at the 0.05 probability level. 
TABLE 4.-Average plant height ( $\mathrm{cm}$ ) and average regrowth percentages (APR\%) at 15, 30 and 45 days intervals during short days season (September to October, 1987)

\begin{tabular}{ccccc}
\hline & \multicolumn{3}{c}{ Days of regrowth } \\
\hline $\begin{array}{c}\text { Identification } \\
\text { P.R.P.I. or } \\
\text { common name }\end{array}$ & 15 days & 30 days & 45 days & APR \\
\hline & & & & \\
3637 & 26 & 69 & $135 \mathrm{a}^{\mathrm{r}}$ & 130 \\
3634 & 23 & 71 & $115 \mathrm{~b}$ & 135 \\
3622 & 27 & 68 & $108 \mathrm{bc}$ & 105 \\
Common & 24 & 60 & $100 \mathrm{cde}$ & 108 \\
13093 & 30 & 57 & $98 \mathrm{cde}$ & 81 \\
12917 & 29 & 73 & $94 \mathrm{de}$ & 90 \\
Sp. & 23 & 60 & $91 \mathrm{e}$ & 106 \\
13606 & 20 & 45 & $78 \mathrm{f}$ & 74 \\
13605 & 16 & 44 & $75 \mathrm{f}$ & 122 \\
Guadalupe & 14 & 37 & $72 \mathrm{f}$ & 129 \\
1987 & 14 & 38 & $53 \mathrm{f}$ & 105 \\
Mean & 22 & 56 & 93 & 108 \\
\hline
\end{tabular}

'Means followed by the same letter or letters do not differ at the 0.05 probability level.

In general, average IVTD estimates were similar for all cultivars under evaluation. With the exception of cultivar PRPI 3622, IVTD estimates for most cultivars were higher during long-day than during short-day season. Cultivar Guadalupe showed consistently the highest IVTD for both seasons.

Table 3 and 4 show average plant height and average regrowth percentages of each cultivar in one of the harvests of each season. As indicated, $P$. maximun PRPI 3637 and 3634 had consistently higher average regrowth percentages (ARP\%), thus indicating an excellent capacity to recover after each harvest. These two cultivars also had the greatest plant height at 45 days of regrowth in both seasons.

\section{LITERATURE CITED}

1. Arroyo-Aguilú, J. A. and J. Coward-Lord, 1974. Relationship between and within physical and chemical constituents and in vitro true digestibility in tropical forage grasses. J. Agric. Univ. P.R. 58 (4): 437-47.

2. Goering, H. K. and P. J. Van Soest, 1970. Forage fiber analyses aparatus reagents procedures and some application. USDa, Agric. Handb., p. 379.

3. Keognan, J. M., P. Philip and G. Proverb. Guinea grass (Panicum maximun) seed production fact sheet. Caribbean Agricultural Research and Development Institute. Order no. AP-F/17-85.

4. Méndez-Cruz, A. V., V. Siberio-Torres, J. Fernández-Van Cleve, E. Fontanet and G. Ramirez-Oliveras, 1988. Yield and nutritive value of hay from five tropical grasses at three harvest intervals. J. Agric. Univ. P.R. 72 (1): 109-18.

5. Mott, G. 0., 1983. Evaluacion del germoplasma forrajero bajo diferentes sistemas de manejo del pastoreo. Germoplasma forrajero bajo pastoreo en pequeñas parcelas. 
Metodologia de evaluación. Memorias de una reunion de trabajo, Cali, Colombia, Sept. 22-24, 1982 RIEPT CIAT, P. 149-150. Editadas por Osvaldo Paladines y Carlos Lascano.

6. Soldevila-Martínez, M., J. Vélez-Santiago, A. V. Méndez-Cruz and D. Jiménez-Tosado, 1979. Manejo y utilización de los forrajes en Puerto Rico. Publ. 125, GT1. Esta. Exp. Agric., Univ. P.R.

7. Sotomayor-Ríos, A., A. Acosta-Matienzo and J. Vélez-Fortuño, 1971. Yield comparison and plant character correlation on 16 Panicum accessions. J. Agric. Univ. P.R. 55 (2): 174-83.

8. Vélez-Santiago, J. and J. A. Arroyo-Aguilú, 1984. Influence of two fertilizer levels on forage and crude protein yields of seven tropical grasses. J. Agric. Univ. P.R. 68 (4): 471 .

9. - A. Sotomayer-Ríos, S. Torres-Rivera and A. V. Méndez-Cruz, 1982. Performance of six Cenchrus and four Panicum forage grasses under cutting management in the Lajas valley, Puerto Rico. J. Agric. Univ. P.R. 44 (4): 268-77.

10. - J. A. Arroyo-Aguilu and J. Rodríguez Arroyo, 1985. Effects of seeding rates and methods on the establishment and yield of common guinea grass, J. Agric. Univ. P.R. 69 (3): 389.

11. Vicente-Chandler, J. and J. Figarella, 1958. Growth characteristics of guinea grass on the semiarid south coast of Puerto Rico. J. Agric. Univ. P.R. 42 (5): 151-60. 